\title{
THE APPROPRIATENESS OF THE LAWYER AS ADVOCATE IN CONTEMPORARY ABORIGINAL JUSTICE INITIATIVES
}

\section{LARRY CHARTRAND}

This article discusses circle sentencing as a means of addressing the high proportion of aboriginal offenders in the prison system and allowing aboriginal communities greater participation in sentencing decisions. The difficulties of continuing the lawyer's role as advocate, a primary duty of lawyers in this process, is also explored.

Ultimately, it is the client's decision whether to allow community participation in sentencing. The article queries whether by allowing community involvement in decision-making, the lawyer is disregarding a commitment to act in the client's interests. For circle sentencing to be effective, not only must the lawyer relinquish the role of advocate, but equally importantly, the client must accept this non-adversarial role. Similarly, the function of the judge must change from passive neutrality to mediation. Until there is legislative reform, the extent to which aboriginal communities may be involved in the sentencing process rests within the judge's discretion.
Le présent article examine le prononcé de sentence dans le cercle comme une façon de traiter le nombre élevé de délinquants autochtones dans le système carcéral et de permettre aux collectivités autochtones de participer davantage à la détermination de la peine. La difficulté de maintenir l'avocat dans son rôle de défenseur, une fonction essentielle dans ce processus, est également exploré.

La décision ultime de permettre la participation de la collectivité incombe au client. L'article examine si, en autorisant cette initiative, l'avocat ne renonce pas à l'engagement qu'il a pris d'agir pour le bien de son client. Pour que ce prononcé de sentence adapté à la culture autochtone soit efficace, l'avocat ne doit pas seulement céder ce rôle de défenseur, mais le client doit accepter ce rôle de non-confrontation. Pareillement, la fonction du juge doit également passer de la neutralité à la médiation. En attendant une réforme législative, il incombe au juge de décider du degré de participation des collectivités autochtones au prononcé de la sentence.

\section{TABLE OF CONTENTS}

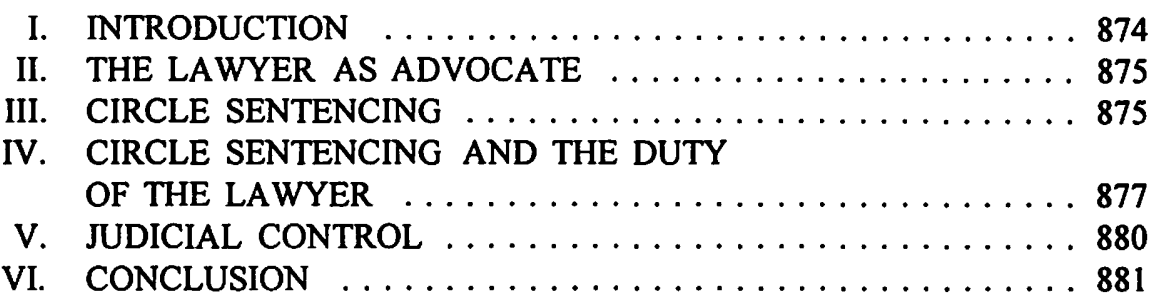

\section{INTRODUCTION}

There is an increasing number of alternative responses to the existing criminal justice system.' These responses are motivated by a number of different factors. Aboriginal communities and non-aboriginal communities see these initiatives as a means to address or minimize the over-representation of aboriginal offenders in the prison system. However, aboriginal communities also see these initiatives as a means of acquiring greater control of or input into the decision-making processes of the justice system.

1 Responses include aboriginal elders panels, aboriginal justice committees, diversion programs and circle sentencing approaches. 
This article will focus on "circle sentencing," which is one particular response that is growing in usage. However, the discussion that follows also has implications for other aboriginal justice initiatives. Circle sentencing is increasingly being relied upon by the system as an alternative to the regular sentencing approach. This unique sentencing approach, however, raises serious questions about the role of the lawyer as an advocate for her client. There is arguably an irreconcilable inconsistency between the circle sentencing process as a means of community decision-making and the role of the lawyer as advocate.

\section{THE LAWYER AS ADVOCATE}

One of the most fundamental professional rules of conduct for lawyers is their duty to act as advocates for their clients. The Alberta Law Society states the rule as follows:

When acting as an advocate the lawyer must, while treating the tribunal with courtesy and respect, represent his client resolutely, honourably and within the limits of the law. ${ }^{2}$

This duty applies throughout the criminal process, including the sentencing stage. For example, a defence lawyer is arguably responsible to a client for ensuring that he or she has obtained the best plea bargain if the client intends to plead guilty. The lawyer must ensure that the facts to be "read in" are appropriate and do not unduly prejudice the client. The lawyer must protect the client's rights while ensuring that the client gets the best possible outcome. The prosecutor is not under any different duty as advocate except that the client he or she represents is the "interests of the state."

In an adversarial system, such duties of advocacy by counsel are necessary to ensure the fair representation of each party. However, do these same concerns apply in a circle sentencing proceeding? Do lawyers have a continuing duty to be advocates for their clients in circle sentencing? If so, is not the integrity and purpose of the circle sentencing thereby compromised?

\section{CIRCLE SENTENCING}

Circle sentencing is an alternative to regular sentencing. The client or community will ask the judge to consider establishing a circle court for determining a sentence. ${ }^{3}$ The aboriginal community is usually enthusiastic about participating in circle sentencing because such a process is more conducive to traditional aboriginal concepts of justice.

Circle sentencing is used regularly in the Yukon, Northwest Territories and in the northern reaches of many provinces. Its use as an alternative to the adversarial

2 The Law Society of Alberta, Professional Conduct Handbook (Calgary: Law Society of Alberta, 1977) at 27.

3 For a recent critique on the circle sentencing trend and the distinction between "process-oriented" circle sentencing, which does not necessarily incorporate traditional forms of sentencing, and those circles that do, see T. Quigley, "Some Issues in Sentencing of Aboriginal Offenders" in R. Gosse et al., eds., Continuing Poundmaker and Riels's Quest (Saskatoon: Purich Publishing, 1994) 268 at 287. 
sentencing approach is gaining prominence in southern parts of the provinces, as well as in urban centres. For example, the Stoney Indian band of the Alexis reserve, west of Edmonton, is in the process of establishing circle sentencing as a "regular" part of the criminal justice system for their community.

The circle process begins by having the usual participants of the justice system sit in a circle with members of the community who have expressed an interest in participating. As Judge Barry Stuart stated in $R$. v. Moses:

By arranging the court in a circle without desks or tables, with all participants facing each other, with equal access and equal exposure to each other, the dynamics of the decision-making process were profoundly changed.... The circle setting dramatically changed the roles of all participants, as well as the focus, tone, content and scope of discussions. ${ }^{4}$

Stuart J. specifically identified a number of "benefits" that the circle process is said to provide the court. They are:

(1) It challenges the monopoly of professionals.

(2) It encourages lay participation.

(3) It enhances the transfer of information.

(4) It facilitates a creative search for new options.

(5) It promotes a sharing of responsibility.

(6) It encourages the offender's participation.

(7) It involves victims in sentencing.

(8) It creates a constructive environment.

(9) It generates a greater understanding of justice system limitations.

(10) It extends the focus of the criminal justice system.

(11) It mobilizes community resources.

(12) It merges values of First Nation and western governments.

The non-adversarial, consensus-based nature of the circle sentencing process is seen as more conducive to aboriginal values of dispute resolution. In the circle sentencing process, the values of aboriginal society gain prominence. Thus, emphasis is placed on rehabilitation rather than punishment, with a view to resolving disputes that will promote the achievement of harmony within the community. As a result, the circle sentence is seen as an alternative that respects aboriginal values and processes of dispute resolution.

The respect for aboriginal values and processes is directly proportional to the degree of control exercised by an aboriginal community over its members' lives. Unfortunately, for hundreds of years, that respect has been taken away from aboriginal communities by the oppressive policies of past and present colonial-based governments. Professor Turpel summarizes the magnitude of the destruction to aboriginal communities by the impact of colonialism as follows: 
From economic and social disempowerment to problems in the criminal justice system, Aboriginal peoples' issues are seemingly indivisible - one crosses over to another in an interconnected and almost continuous fashion. Alcoholism in Aboriginal communities is connected to unemployment. Unemployment is connected to the denial of hunting, trapping and gathering economic practices. The loss of hunting and trapping is connected to dispossession of land and the impact of major development projects. Dispossession of land is in tum connected to loss of culture and spiritual identity and is a manifestation of bureaucratic control over all aspects of life. This oppressive web can be seen as one of disempowerment of communities and individual Aboriginal citizens. ${ }^{6}$

Aboriginal communities must begin a process of restoration to heal themselves. That restoration process begins with respect. To regain respect, members of aboriginal communities must have control over their lives, including control over their social order systems. Circle sentencing can be seen as an important building block in the process of restoring aboriginal community respect and healing. In the circle sentencing process, this restoration can be achieved by allowing the community to have final control over the decision-making that determines the appropriate disposition for an offender.

\section{CIRCLE SENTENCING AND THE DUTY OF THE LAWYER}

At first appearance, it might seem that by accepting the circle sentence approach, the lawyer is compromising his or her duty to the client as advocate. Since the purpose of the circle sentence is to achieve a consensus as to the appropriate sentence for the accused, is the lawyer not relinquishing his or her responsibility to represent the client resolutely? In particular, is the lawyer in breach of the rules of professional misconduct? On the duty as advocate, Commentary 1(d) of the Law Society of Alberta's Handbook, states that the lawyer must not

endeavour or allow anyone else to endeavour, directly or indirectly, to influence the decision or action of a tribunal or any of its officials in any case or matter, whether by bribery, personal approach or any means other than open persuasion as an advocate. ${ }^{\text {? }}$

In other words, a lawyer is allowing members of the community to influence the judge in circle sentencing, and it is possible that such influence may not be in the best interests of the client. Unlike a pre-sentence report, for example, individuals give more than just information about the client for the judge's benefit. Members of the community often give their opinions on what the sentence should be, opinions that may be adverse to what the client thinks he or she should reasonably receive.

However, certain members of the bar and judiciary would argue that it is possible to maintain one's duty as an advocate to the client and still allow the client to participate in the circle sentence process. Stuart J. in Moses stated that the "traditional

- M.E. Turpel, "On the Question of Adapting the Canadian Criminal Justice System for Aboriginal Peoples: Don't Fence Me In" in Royal Commission on Aboriginal Peoples, Aboriginal Peoples and the Justice System (Ottawa: Minister of Supply and Services, 1993) 161 at 166. 
and essential functions of Crown and defence counsel are not excluded by the circle."8 Both defence and Crown are given the usual opportunities to speak to sentence. The only difference is that the community is then allowed to provide its input. Stuart $\mathrm{J}$. argues that the role of the Crown is actually facilitated because he or she can use the comments and views of the members of the community in the circle to determine what sentence would be best to protect that community. ${ }^{9}$ After all, it is that very community which Crown submissions are designed to protect. Defence counsel, too, can constructively use the circle to develop a sentencing option to advance both the immediate and long-term interests of the client in a process in which community support can create alternatives to jail.

Certain members of the bar who have been involved in circle sentencing maintain that it is the lawyer's responsibility to the client to continue being an advocate to ensure that the client's interests are protected. Allowing the community to participate in the sentencing process is a decision that rests with the accused. The accused has the ultimate decision as to whether he will participate in a circle sentencing process or not. As long as the lawyer informs her client of the options and risks involved, she is not in breach of her duty to her client. Furthermore, if the client elects to participate in the circle sentencing process, the lawyer can still maintain the role of an advocate. If a member of the community begins to make statements against the client's best interests, the lawyer can take on a more active role as advocate within the circle. For example, the lawyer could protect the client by challenging a speaker's credibility.

There comes a point, however, where the lawyer's protection of the client's interests threatens the very purpose of having the circle sentencing process in the first place. The more the lawyer acts as an advocate in directing his remarks to the judge, knowing that the decision of sentencing remains within the judge's discretion, the more the process is transformed. Essentially, the role of the community becomes depreciated and weakened, to the point where its members become mere observers, in a traditional adversarial setting.

In other words, the role of the lawyer as advocate diminishes the role of the community as a participant in the process. From an aboriginal community healing perspective, this outcome is contrary to the very purpose of the circle sentencing process, which is to have the aboriginal community regain a measure of control over the justice system in a manner more conducive to its traditional methods of dispute resolution.

Can a lawyer be respectful of the community and maintain her role as advocate? In the United States, aboriginal tribes have jurisdiction over criminal law. The Navajo Nation, for example, has established a dispute resolution process called the Peacemaker Court. The purpose of this court is to provide the Navajo community with an inexpensive and simple system based on standards of Navajo tradition and custom. Under the system, the "Peacemaker" acts very much like a mediator, helping the parties 
to come to a consensus on what is the most harmonious solution to the dispute. One of the most important rules of this court is that no lawyers are allowed to participate. The adversarial process is avoided and the role of the lawyer as advocate is no longer appropriate. Indeed, it is felt to be counter-productive.

In other words, for the circle sentencing process to function as intended (i.e. as a process for the community to actively participate in reaching an appropriate sentence based on community consensus), and not as a more elaborate version of a pre-sentence report, the lawyer must relinquish the role of advocate. This is a case where the best of both worlds is simply not possible.

A client must either fully accept or fully reject the circle sentencing process. If the client accepts it, the client must understand that his lawyer is no longer an advocate. The lawyer can still participate, but as a resource person and not as an advocate. If this role change is made clear to the client, and the client accepts this non-adversarial role, then the lawyer should remain within the boundaries of ethical propriety while according full respect to the aboriginal community.

The inconsistency between circle sentencing and the role of the lawyer as advocate is well illustrated when opposing counsel rejects the circle sentencing process. For example, in $R$. v. Morin, ${ }^{10}$ the Crown counsel objected to the sentencing circle because of the accused's lengthy criminal record. Nevertheless, the judge ruled in favour of a sentencing circle. The Crown advised the circle that she was requesting seven to nine years imprisonment since the accused had committed armed robbery with violence. The consensus of the circle was that the accused should receive eighteen months in jail. The Crown refused to accept the consensus of the circle and insisted that she would not consider anything less than seven years. With a few minor changes, the judge accepted the consensus of the circle.

In this case, the Crown maintained throughout that she thought the best interests of her client, the state, were served by insisting on seven or more years in jail. In other words, it became a contest between the community and the prosecutor. The role of the community was therefore transformed from one of active decision-maker to that of advocate on behalf of its own position. This is unlike the role of a probation officer giving a pre-sentence report. The judge in Morin characterized the role as such:

A pre-sentence report is usually done by a probation officer who interviews the persons necessary to give him or her the information covered in the report.

It appears to me that same type of information is obtainable at a sentencing circle, where the persons who would give the information to the probation officer for a pre-sentence report are present in the circle. If a pre-sentence report can be used by a judge to gain information about the offender, then why can't a sentencing circle be used for the same reason?" 
Although a circle sentence process could function as a pre-sentence report, the point is not whether the circle functions like a pre-sentence report, but whether the community has a true decision-making role or not. If one of the counsel objects to the circle then the purpose of the circle as a process for the aboriginal community to have genuine input into the decision-making process and the ability to come to a true consensus consistent with traditional norms of harmony is seriously compromised. In Morin, the result was the absurd situation of the prosecutor, whose role is to serve the interests of the community, competing with that very same community. The lawyer's role in circle sentencing must be absolutely passive. Otherwise, from the aboriginal communities' perspective, the entire process is fraudulent.

\section{JUDICIAL CONTROL}

Until such time as substantive changes are made through legislation, ${ }^{12}$ the judiciary will continue to have the discretion to determine the nature of the sentencing process. Thus, the extent to which the circle sentencing process will be a vehicle for true community input in the decision-making process is up to the judge.

If the judge is to give full respect to the aboriginal community, then his or her role must also change from being the focus of attention and authority to one where he or she largely concedes the decision-making authority to the community. The role of the judge has traditionally been one where the judge is intended to be passive and neutral. The proper role of the judge is one where he or she sits back and listens to counsel for each side, intervening as little as possible. Of fundamental importance is the requirement that the judge be completely impartial to the parties involved. Such is the hallmark of ensuring that the rule of law is maintained and the system is truly just.

The judge's role in circle sentencing, if he or she is to even have a role, would be that of a mediator. ${ }^{13}$ In such a role, the judge would assist the community in arriving at a consensus of the best disposition for the accused. In undertaking such a role, judicial responsibility for ensuring impartiality and neutrality is not jeopardized. As a mediator, the judge can still maintain his or her neutrality in guiding the community to a consensus. As a mediator, however, the judge's role would change from one of passivity to one of active intervention as a facilitator in the process. Although such a role is not normal judicial behaviour, it does not necessarily threaten the rule of law or the ultimate fairness of the hearing.

Until the procedural laws change, the judge still holds the ultimate discretion over sentencing under the Criminal Code. Nonetheless, it is possible to give the aboriginal community the respect it deserves by according it full decision-making authority,

Legislation may be enacted which either gives full decision-making authority to aboriginal communities in sentencing or is broader in scope, and includes most or all of the criminal process. Legislation by aboriginal governments, under the inherent right to control social order within their communities, or by the Federal government, is the desired response.

13 Again, unless substantive changes are made by legislation, the judge would have to, at a minimum, be present at the hearing. Otherwise he or she runs the risk of breaching his or her duties under the Criminal Code to decide matters of sentencing. 
assuming, of course, that the judge would uphold every decision made by the community. ${ }^{14}$ Furthermore, the judge can be instrumental in encouraging counsel to acknowledge the incompatibility of the role as advocate in the circle sentencing process.

\section{CONCLUSION}

Aboriginal communities are becoming more concerned with having meaningful input into the justice system; it is presently a foreign and imposed system which does not serve their needs. Circle sentencing is an option for aboriginal communities to take back some control over the justice system. They are going to demand its application more and more in the years to come. In order to ensure that we give these aboriginal communities the respect they deserve in these initiatives, we must ensure that the circle sentencing process is genuine and a true reflection of the communities' collective ownership of the judicial decision-making process.

Lawyers must be aware of the dilemma between their role as advocates and the nature of the non-adversarial circle sentencing process. Because of the inconsistency between true consensus decision-making and the role of the lawyer as advocate, it is necessary and incumbent on the provincial law societies to provide some guidance to practicing lawyers when they are confronted with the option of having a circle sentencing process for their clients.

14 There will, unfortunately, always be the problem of a higher court overturning the judge's and community's joint decision. This can be minimized by the degree to which both defence and Crown counsel "buy" into the right of the community to have the ultimate say in sentencing decisions. 